\title{
PENGEMBANGAN APLIKASI SINIBID UNTUK PENILAIAN PRAKTIK KEBIDANAN
}

\author{
Yulia Herawati 1 ${ }^{1)}$, Nur aini ${ }^{2)}$ Daniah $^{3)}$ \\ 1,2,3 STIKes Mitra RIA Husada \\ Email: 1r2ddaniah@gmail.com
}

\section{Diterima: November 2021, Diterbitkan: Desember 2021}

\begin{abstract}
Abstrak
Pandemi COVID-19 menyebabkan dampak yang luas terhadap berbagai sektor terutama pendidikan. Negara di seluruh dunia menerapkan kebijakan untuk mencegah penularan dengan membatasi pertemuan tatap muka di sekolah maupun universitas dengan pembelajaran e-learning. Bagi mahasiswa kesehatan seperti kebidanan STIKes Mita RIA Husada Jakarta yang menerapkan pembelajaran praktik perlu terobosan agar evaluasi keterampilan berjalan optimal. Tujuan penelitian ini adalah untuk mengembangkan aplikasi berbasis website untuk pembelajaran praktik klinik mahasiswa bidan di masa pandemi Covid-19 dan menguji user experience Metode yang digunakan dalam studi ini metode Analysis, Development, Implementasi, Evaluasi (ADIE) serta menggunakan desain non eksperimen (observasional) dengan pendekatan Technology Acceptance Model (TAM). Pada tahap evaluasi User Experience pengumpulan data online menggunakan tools User Experience Questionnare (UEQ). Populasi dan sampel adalah mahasiswa sarjana terapan kebidanan SMRHJ sebanyak 41 orang. Hasil penelitian analisis SMRHJ menggunakan paper ceklist dalam penilaian praktik. Pada pengembangan telah dihasilkan aplikasi SINIBID untuk penilaian praktik kebidanan berbasis website dengan link http://sinibid.id/. Hasil uji user experience beberapa kelompok kategori pengujian UEQ yaitu daya tarik aplikasi diatas arata-rata $(1,23)$, dari segi kejelasan aplikasi dibawah rata-rata $(0,77)$, dalam hal effesiensinya diatas rata-rata $(1,19)$, ketepatan aplikasi dibawah rata-rata $(1,06)$, stimulasi aplikasi baik $(1,42)$, dan kebaruan juga dinyatakan baik $(1,27)$. Kesimpulan: aplikasi SINIBID bermanfaat dan baik untuk digunakan dalam proses pembelajaran mahasiswa kebidanan. aspek kejelasan yang masih kurang disiasati dengan menambahkan petunjuk penggunaan.
\end{abstract}

Kata Kunci: Aplikasi, UEQ, Kebidanan, Mahasiswa

\begin{abstract}
COVID-19 pandemic has had a wide impact on various sectors, especially education. Countries around the world are implementing policies to prevent transmission by limiting face-to-face meetings at schools and universities with e-learning. For health students, such as midwifery STIKes Mita RIA Husada, who apply practical learning, they need a breakthrough so that the evaluation of skills runs optimally. The purpose of this study is to develop a website-based application for learning the clinical practice of midwife students during the Covid-19 pandemic and to test the user experience. The method used in this study is the Analysis, Development, Implementation, Evaluation (ADIE) method. In the User Experience evaluation stage, online data collection uses the User Experience Questionnaire (UEQ) tools. The population and sample were 41 students of applied midwifery SMRHJ. The results of the SMRHJ analysis used a paper checklist in a practice assessment. During the development, the SINIBID application has been produced for website-based midwifery practice assessment with the link http://sinibid.id/. The results of the user experience test for several groups of UEQ testing categories, namely the attractiveness of the application above the average (1.23), in terms of application clarity below the average (0.77), in terms of efficiency above the average (1.19), application accuracy is below average (1.06), application stimulation is good (1.42), and novelty is also stated to be good (1.27). Conclusion: the SINIBID application is useful and good for use in the learning process of midwifery students. aspects of clarity that are still lacking to be addressed by adding instructions for use.
\end{abstract}

Keywords: app, UEQ, midwifery, student 


\section{PENDAHULUAN}

Virus Covid-19 masih menjadi topik perbincangan utama sejak kemunculannya pada awal Desember tahun 2019. Pandemi COVID-19 telah menyebabkan pemerintah di berbagai belahan dunia menerapkan sejumlah kebijakan untuk mencegah penularan serta dampak ikutannya, tidak terkecuali pemerintah Republik Indonesia. Sebagai upaya percepatan penanganan COVID-19 pemerintah melalaui PP No. 21 Tahun 2020 menerbitkan kebijakan pembatasan sosial berskala besar (social distancing) terkait aktivitas kerja, dunia usaha, perkantoran, pendidikan, keagamaan, ekonomi ataupun aktivitas sosial lainnya. Khusus terkait dengan dunia pendidikan, pemerintah telah mengubah moda pembelajaran di sekolah ataupun perguruan tinggi sejak 16 Maret 2020 hingga waktu yang belum ditentukan para siswa dan mahasiswa itu kembali aktif ke sekolah ataupun kampus masing-masing. Pembelajaran yang sebelumnya mewajibkan tatap muka secara langsung di kelas diganti dengan pembelajaran online menggunakan berbagai media eletronik sehingga secara umum dapat dikategorikan sebagai $e$ learning (Zhu et al., 2020)

Sistem pembelajaran online mutlak diperlukan mengantisipasi perkembangan jaman dengan dukungan teknologi Informasi dimana semua menuju ke era digital (era revolusi industri 4.0), baik mekanisme maupun konten yang digunakan ${ }^{(2)}$. Seiring dengan perkembangan teknologi yang kian pesat, pembelajaran daring juga merupakan salah satu cara untuk meningkatkan kualitas pendidikan memasuki era revolusi industri 4.0. Untuk memperlancar pelaksanaan pembelajaran daring selama pandemi Covid19 perlu didukung oleh beberapa komponen, data diambil berdasarkan kajian pustaka dan pengalaman dari pengajar seperti infrastruktur, sistem dan aplikasi, konten dan operator. Hal ini juag menjadi kendala bagi mahasiswa kebidan di masa pandemi Covid19.

Penelitian ini bertujuan untuk mengembangkan aplikasi berbasis website untuk pembelajaran praktik klinik.

\section{METODE PENELITIAN}

Metode yang digunakan dalam studi ini metode $A D I E$. menggunakan desain non eksperimen (observasional) dengan pendekatan Technology Acceptance Model (TAM), tahap evaluasi menggunakan adalah pemanfaatan tempate User Experience Questionnare (UEQ).(Schrepp et al., 2017) Kuesioner terdiri dari 26 item, gambar 3 menunjukan kuisioner UEQ yang sudah diadaptasi dalam versi bahasa Indonesia. Sampel adalah mahasiswi sarjana terapan kebidanan sebanyak 41 orang.

\section{Gambar 1. Kuesioner UEQ}

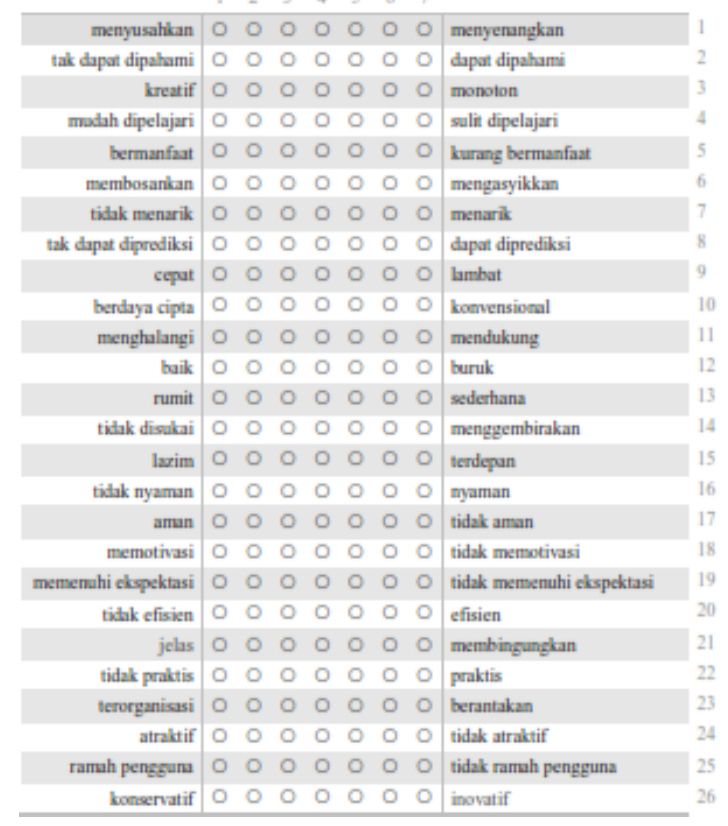

Sebelumnya responden diberitahu dan sosialisasi aplikasi SINIBID, kemudian diminta untuk menggunakan langsung dengan melakukan penilaian praktik kebidanan. Pengumpulan umpan balik dari kuesioner tersebut dilakukan melalui online menggunakan google form. Pengambilan respon terhadap kuisinoer dilakukan dengan rentang waktu satu minggu namun dengan waktu pengisian maksimal selama 15 menit, sesuai dengan petunjuk dari kuisioner UEQ bahwa diharuskan memutuskan penilaian secara spontan.

Kemudian data dianalisis dengan 
menghitung rata- rata dari enam skala yang sudah ditetapkan. Alat yang digunakan adalah Excel-Tool yang diunduh melalui situs ueq-online.org. Hasil evaluasi akan secara otomatis bisa didapatkan dengan cara memasukan data-data kuesioner ke dalam Excel- Tool.

\section{HASIL DAN PEMBAHASAN}

Tahapan awal adalah menganalisis dari kebutuhan dengan menggunakan wawancara pada mahasiswa yaitu perlu adanya aplikasi yang memudahkan mahasiswa dalam melakukan penilaian praktik kebidanan pada mata kuliah yang menggunakan daftar tilik . selama ini SMRHJ menggunakan paper dan excel baik pada saat latihan maupun saat ujian.

Pada tahap pengembangan ini adalah membuat antarmuka aplikasi mobile dan aplikasi web sesuai dengan rancangan yang telah dibuat sebelumya ke dalam bentuk surce code atau kode program. Halaman antarmuka terdiri dari

a. Halaman Register dan Login

\section{Gambar 2. Halaman Login}
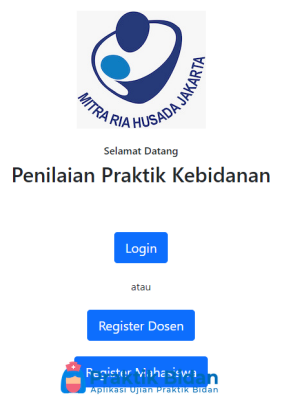

b. Halaman Beranda

\section{Gambar 3. Halaman Beranda}

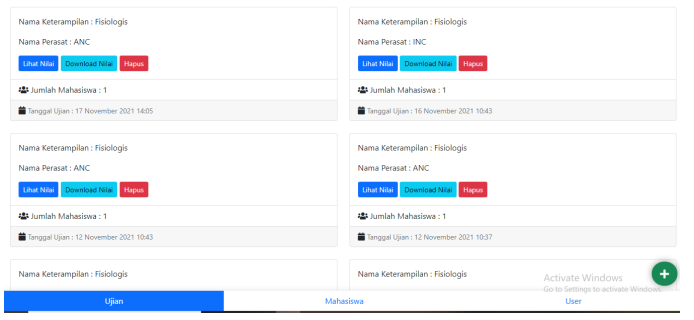

c. Halaman isi

\section{Gambar 4. Halaman Isi}

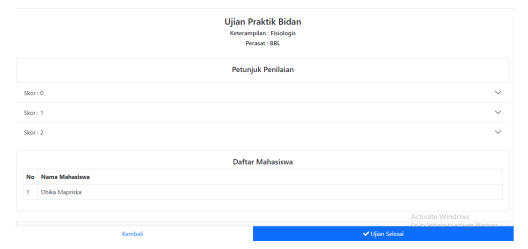

Selanjutnya pada tahap evaluasi dilakukan Pengukuran user experience pengembangan aplikasi SINIBID menggunakan UEQ dilkukan secara online dengan menggunakan google form.

\section{Pengujian Aplikasi}

Hasi pengujian seperti yang terdapat pada gambar 5 menunjukan skala tersebut bernilai positif karena berada pada skala diatas 0 .

\section{Gambar 5. Skala Uji}

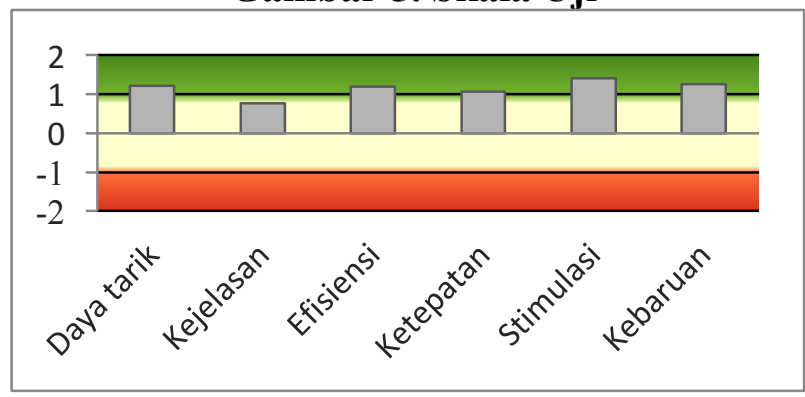

Secara terperinci, hasil pengukuran seperti yang ada pada Tabel 1

\section{Tabel 1 Hasil Rata-Rata Skala UEQ}

\begin{tabular}{ll}
\hline Skala & Rata-Rata \\
\hline Daya tarik & 1,23 \\
Kejelasan & 0,77 \\
Efisiensi & 1,19 \\
ketepatan & 1,06 \\
Stimulasi & 1,42 \\
Kebaruan & 1,27 \\
\hline
\end{tabular}

Untuk mengetahui arti dari nilai yang dihasilkan oleh setiap skala UEQ dilakukan dengan cara membandingkan nilai hitung masing-masing skala dengan nilai standar. Perbandingan Mean Hasil perhitungan UEQ dibandingkan dengan nilai standar yang ada untuk menentukan signifikansi masing-masing nilai. 


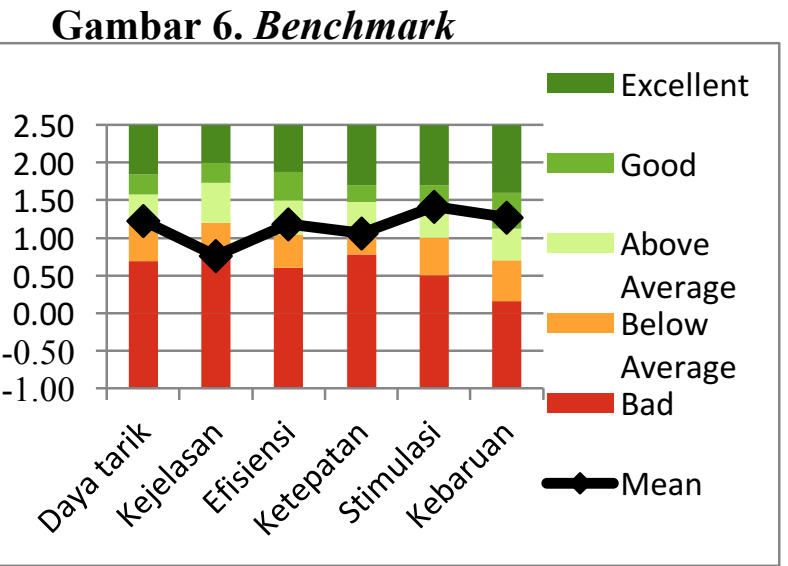

Perbandingan nilai hasil pengolahan dengan benchmark yang terdiri dari aspek stimulasi nilainya baik (good) artinya pengguna atau responden merasa aplikasi ini bermanfaat, menarik dan sedikit memotivasi untuk menggunakan. Pada nilai kebaruan nilainya (good) artinya inovatif, berdaya cipta dan kreatif. Aspek daya tarik dan efisiensi diatas rata2 dan aspek kejelasan dan ketepatan dibawah rata-rata sehingga pada poin tersebut perlu diperhatikan dan diprioritaskan untuk diperbaiki.

\section{Gambar 7. Tabel Rata- Rata Hasil Pengukuran UEQ}

\begin{tabular}{|c|c|c|c|c|c|c|}
\hline Item |Mean & Variance & td. Deł & No. & Lefft & Right & Scale \\
\hline \begin{tabular}{|l|l|}
1 & i 1,7 \\
\end{tabular} & 1,1 & 1,0 & 41 & menyusahkan & menyenangkan & Daya tarik \\
\hline \begin{tabular}{l|l}
2 & $\widehat{2}, 0$ \\
\end{tabular} & 1,1 & 1,0 & 41 & tak dapat dipahami & dapat dipahami & Kejelasan \\
\hline \begin{tabular}{|l|l|}
3 & 1 \\
\end{tabular} & 1,4 & 1,2 & 41 & kreatif & monoton & Kebaruan \\
\hline \begin{tabular}{l|l}
4 & $-1,9$ \\
\end{tabular} & 1,2 & 1,1 & 41 & mudah dipelajari & sulit dipelajari & Kejelasan \\
\hline \begin{tabular}{|l|l|}
5 & \multicolumn{2}{|c}{2,1} \\
\end{tabular} & 0,9 & 0,9 & 41 & bermanfaat & kurang bermanfaat & Stimulasi \\
\hline \begin{tabular}{|l|l|}
6 & $1,1,7$ \\
\end{tabular} & 1,2 & 1,1 & 41 & membosankan & mengasyikkan & Stimulasi \\
\hline \begin{tabular}{l|l}
7 & 1,6 \\
\end{tabular} & 1,4 & 1,2 & 41 & tidak menarik & menarik & Stimulasi \\
\hline \begin{tabular}{l|l|}
8 & 1,5 \\
\end{tabular} & 1,7 & 1,3 & 41 & tak dapat diprediksi & dapat diprediksi & Ketepatan \\
\hline \begin{tabular}{l|l|l|l}
9 & 1,8 \\
\end{tabular} & $\frac{1,1}{1,7}$ & 1,3 & 41 & cepat & lambat & Efisiensi \\
\hline $\begin{array}{cc}10 & \Rightarrow>0,5\end{array}$ & $\frac{1,4}{1,4}$ & $\frac{1,2}{1,2}$ & 41 & berdaya cipta & konvensional & Kebaruan \\
\hline \begin{tabular}{|l|l|}
11 & 1 \\
\end{tabular} & $\frac{1,7}{1,6}$ & $\frac{1,2}{1,3}$ & 41 & menghalangi & mendukung & Ketepatan \\
\hline \begin{tabular}{l|l}
12 & 1,0 \\
1,8
\end{tabular} & $\frac{1,0}{1,7}$ & 1,3 & 41 & baik & buruk & Daya tarik \\
\hline \begin{tabular}{|l|l|}
13 & 1,2 \\
\end{tabular} & 1,9 & 1,4 & 41 & 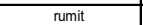 & sederhana & Kejelasan \\
\hline \begin{tabular}{|l|l|}
14 & $\wedge$ \\
14,9
\end{tabular} & 1,8 & 1,3 & 41 & tidak disukai & menggembirakan & Daya tarik \\
\hline \begin{tabular}{|l|l|}
15 & 1,5
\end{tabular} & 2,4 & 1,6 & 41 & lazim & terdepan & Kebaruan \\
\hline \begin{tabular}{l|l}
16 & 1,9 \\
\end{tabular} & 1,2 & 1,1 & 41 & tidak nyaman & nyaman & Daya tarik \\
\hline \begin{tabular}{|l|l|}
17 & 1,8 \\
\end{tabular} & 1,7 & 1,3 & 41 & aman & tidak aman & Ketepatan \\
\hline $18 \Rightarrow>0,3$ & 4,3 & 2,1 & 41 & memotivasi & tidak memotivasi & Stimulasi \\
\hline \begin{tabular}{l|l}
10 & $-1,3$ \\
19 & $-2,9$
\end{tabular} & $\frac{4,3}{2,7}$ & $\frac{2,1}{1,7}$ & $\frac{41}{41}$ & memenuhi ekspektasi & tidak memenuhi ekspektasi & Ketepatan \\
\hline $\begin{array}{l}13 \\
20\end{array}$ & $\frac{2,1}{2,7}$ & $\frac{1,7}{1,7}$ & $\frac{41}{41}$ & tidak efisien & efisien & Efisiensi \\
\hline \begin{tabular}{|l|l|l|l|l}
21 & 1,8
\end{tabular} & $\frac{2, r}{0,8}$ & 0,9 & 41 & jelas & membingungkan & Kejelasan \\
\hline \begin{tabular}{|l|l|l|}
22 & $1,1,5$
\end{tabular} & $\frac{1,0}{1,4}$ & $\frac{0,2}{1,2}$ & 41 & tidak praktis & praktis & Efisiensi \\
\hline \begin{tabular}{c|c|c|}
23 & $\Rightarrow>0,1$
\end{tabular} & $\frac{1,4}{3,0}$ & $\frac{1,2}{1,7}$ & 41 & terorganisasi & berantakan & Efisiensi \\
\hline $24 \Rightarrow>0,0$ & 2,5 & 1,6 & 41 & atraktif & tidak atraktif & Daya tarik \\
\hline \begin{tabular}{l|l}
25 & $\Rightarrow>0,2$ \\
\end{tabular} & 3,1 & 1,8 & 41 & ramah pengguna & tidak ramah pengguna & Daya tarik \\
\hline \begin{tabular}{|l|l|}
26 & 1,3 \\
\end{tabular} & 1,6 & 1,3 & 41 & konservatif & inovatif & Kebaruan \\
\hline
\end{tabular}

\section{KESIMPULAN}

Berdasarkan analisis, perancangan, pengembangan, implementasi, dan pengujian yang telah dilakukan pada pengembangan sistem informasi geografis layanan umum berbasis Website, diperoleh kesimpulan sebagai berikut.

1. Pengembangan dan Perancangan Sistem Informasi Layanan Umum Berbasis website telah berhasil dilakukan sesuai rancangan kebutuhan sistem,

2. Respon pengguna terhadap sistem yang di kembangkan sangat positif. Rata-rata pencapaian pengujian User Experince Questionnaire (UEQ) sebagian besar memiliki nilai yang baik Adapun hasil dari beberapa kelompok kategori pengujian UEQ yaitu daya tarik aplikasi diatas arata-rata $(1,23)$, dari segi kejelasan aplikasi dibawah ratarata $(0,77)$, dalam hal effesiensinya diatas rata-rata $(1,19)$, ketepatan aplikasi dibawah rata-rata $(1,06)$, stimulasi aplikasi baik $(1,42)$, dan kebaruan juga dinyatakan baik $(1,27)$

\section{UCAPAN TERIMAKASIH}

Terimakasih kepada STIKes Mitra RIA Husada dan LLDIKTI 3.

\section{DAFTAR PUSTAKA}

Aidah, S. (2019). Pemanfaatan e-learning sebagai media pembelajaran di STIA AL GAZALI BARRU (suatu studi terhadap pemanfaatan model e-learning berbasis software claroline). Meraja Journal, 2(1), 1-12.

Ally, M. (2004). Foundations of Educational Theory for Online Learning. In Theory and practice of online learning (pp. 15-44). https://doi.org/10.1007/978-1-40208299-3 8;

Alshwaier, $\bar{A}$. (2012). A New Trend for ELearning in KSA Using Educational Clouds.

Carliner, S. (1999). Overview of online learning. Human Resource Development Press

Dep.Kes.RI. Pedoman Organisasi Dan Tatalaksana Politeknik Kesehatan. Badan Pengembangan Dan

Guna, S. D., \& Nita, Y. (2019). Uji Validitas Dan Reliabilitas Kuesioner Pengukuran Kompetensi Sistem Informasi Keperawatan. HEALTH CARE: JURNAL KESEHATAN, 8, 1, pp. 39 - 43. DOI: https://doi.org/10.36763/healthcare.v8i 
1.3

Guna, S.D, Nita, Y, \& Premono, S.J. (2020).

Barriers and Opportunities of Using Electronic Nursing Record in Indonesia: Nurses' Perspective. ICIC Express Letters Part B: Application. Vol. 11, no. 12, pp. 1159- 1164, DOI: 10.24507/icicelb.11.12.1159

Guna, S. D., \& Nita, Y. (2021). Kemampuan Informatika Perawat Sebagai Modal Penerapan Pencatatan Keperawatan Elektronik di Rumah Sakit. Jurnal Keperawatan Muhammadiyah, 6(2). DOI: http://dx.doi.org/10.30651/jkm.v6 i2 27763

Indra Mulyaningsih, N. N. (2017). Pengembangan Pembelajaran Berbasis Riset di Jurusan Tadris Bahasa Indonesia FITK IAIN Syekh Nurjati Cirebon. Journal Indonesian Language Education and Literature, 120-125.

Pemberdayaan SDM Kesehatan, Jakarta. 2003

Kemendikbud. (2020). KBBI daring. Https://Kbbi.Kemdikbud.Go.Id. https://kbbi.kemdikbud.go.id/entri/dari ng

Mirza, A. (2007). Is E-learning finally gaining legitimacy in Saudi Arabia? Saudi Computer Journal,. Saudi Computer Journal, 6(2), 1-14. 